\title{
Embedded Discourses: Nigerien Academic Contributions to Land Use Change Research Since the 1960s
}

\author{
Sarah Ann Lise D'haen ${ }^{1}$, Ibrahim Bouzou Moussa ${ }^{2} \&$ Anette Reenberg ${ }^{1}$ \\ ${ }^{1}$ Department of Geosciences and Natural Resource Management, Faculty of Science, University of Copenhagen, \\ Copenhagen K, Denmark \\ ${ }^{2}$ Département de Géographie, Faculté des Lettres et Sciences Humaines, Université de Niamey, Niamey, Niger \\ Correspondence: Sarah Ann Lise D'haen, Department of Geosciences and Natural Resource Management, \\ Faculty of Science, University of Copenhagen, Øster Voldgade 10, 1350 Copenhagen K, Denmark. Tel: \\ 45-35-322-547. E-mail: sdh@geo.ku.dk
}

Received: May 2, 2013 Accepted: June 10, 2013 Online Published: June 24, 2013

doi:10.5539/jsd.v6n7p69 URL: http://dx.doi.org/10.5539/jsd.v6n7p69

\begin{abstract}
On the basis of a systematic screening of research papers, this study explores the land use and land cover change research priorities of scholars from Niger since independence. It investigates how key interests have evolved over time with regard to what issues are considered important as well as the researchers' assessments of changes in the Sahel and their driving forces. In doing so a) it identifies the dominant characterization of land changes and their implication, and b) it explores the possible change over time with regard to focus of interest in the national science community. The available pool of scientific publications is screened by use of a meta-study approach, followed by a hierarchical cluster analysis of identified key variables, to synthesize existing knowledge. The meta-study reveals that no land research was communicated through scholarly papers before the early 1990s. Since 1994, the Nigerien academic research on land change has documented a diverse range of changes (e.g. expansion, intensification, conservation, tenure); yet the material cannot support general conclusions about dominant trajectories of change. Different human-environmental discourses have influenced the research questions in different regions and time periods, with implications for the problems addressed in specific case studies. It is concluded that the collective insight into land change processes reveals land system complexities rather than generic trends.
\end{abstract}

Keywords: land use/land cover change, African researchers, meta-analysis, West Africa, Niger

\section{Introduction}

For the last forty years, human-environment relationships have been a prominent theme of international academic research in the West African Sahel, sparked by the severe droughts experienced by this region in the early 1970s. The use of land has a prominent position in the research because it is acknowledged that land management plays a pivotal role in the dynamics and sustainability of the human-environmental systems.

When looking more closely at the Sahel research published internationally in the course of the past four decades, it appears that slightly changing narratives have prevailed in the broader development community and have influenced the direction of the strategic research initiatives. Generally speaking, three major epochs have been distinguished (Reenberg, 2012). In the 1970s, research was focused on desertification, represented by concerns about, for example, whether and how fast the Sahara was expanding, as well as clarifying the root causes of the change (biophysical or human explanations). In the 1980s-90s, dryland degradation in a broader sense of the term became the main focus, with emphasis on the notions of sustainable Natural Resource Management in land systems. Most recently, in the 2000s, climate change adaptation has become the headline of many of the research efforts, with themes such as coping strategies, resilience, and vulnerability at the center of research portfolios. Notwithstanding the shift in the overarching narrative, land system analyses have provided important contributions to research about human-environmental interaction in the Sahel.

In fact, initial research efforts on land change in the Sahel were embedded in a land degradation and desertification paradigm closely associated with a neo-Malthusian narrative that linked population pressure and low rainfall to unsustainable agricultural expansion and land degradation. Even though this narrative still 
dominates major policy formulations (Reenberg, 2012), it can be observed that from the late 1990s academic research has increasingly recognized the complexity of the dynamics and socio-ecological feedbacks in land systems in the Sahel, and the important role of land users' resourcefulness (e.g. Reij \& Smaling, 2008; Rasmussen \& Reenberg, 2012).

Despite the apparent awareness of the crucial importance of land use, the theoretical and conceptual understanding of the land change processes in the Sahel remains, however, poorly supported by hard empirical evidence from systematic case studies. A recent meta-study of peer reviewed empirical case studies on cropland change in the Sahel (van Vliet, Reenberg, \& Rasmussen, 2013) found remarkably few papers in the entire pool of Anglophone literature scrutinized. The authors identified some indicative trends, such as increased cropland since 1960 in $73 \%$ of the available studies, which in most cases was associated with a population density increase (Reenberg, Nielsen, \& Rasmussen, 1998; Gray, 1999; Tappan, Sall, Wood, \& Cushing, 2004; Mortimore \& Turner, 2005; Leblanc et al., 2008; Mbow, Mertz, Diouf, Rasmussen, \& Reenberg, 2008; Pare, Soderberg, Sandewall, \& Ouadba, 2008; Ouedraogo et al., 2009; Ruelland, Levavasseur, \& Tribotte, 2010) or in-migration (Gray, 1999; Wardell, Reenberg, \& Tettrup, 2003; Tappan et al., 2004; Wood, Tappan, \& Hadj, 2004; Mortimore \& Turner, 2005; Pare et al., 2008; Ouedraogo et al., 2009).

Empirical material from Niger appears to be especially scarce (van Vliet et al., 2013) in the widely published Anglophone literature. On this background, the current paper aims at casting the net more broadly to identify the potential pool of insight from a broader range of published sources, with specific emphasis on scholarly work presented by Nigerien researchers.

Based on a systematic screening of Nigerien scientific publications on land use/land cover change, our objective is a) to investigate to what extent published national research efforts on land use/land cover in Niger deepen the insight in land change in this country, and b) to explore thematic interests of the Nigerien scholars. To achieve this objective we first identify the pool of research results distilled from the national research efforts; second, we explore the possible change in focus of interest in the national science community over time, and finally, we identify the dominant Nigerien narratives of land change and their implications.

\section{Land Use/Land Cover Change in Niger: Background}

According to the United Nations Food and Agricultural Organization, FAO (2012), the share of arable land out of the total land area has increased in Niger since the 1960s. Arable land amounted to $12 \%$ in 2008, according to these FAO estimates, and includes areas under temporary agricultural crops, temporary pasture, or temporary fallow (as opposed to permanent crops and pasture).

There are considerable local variations in land use strategies and their development (Raynaut, 1997), all of which cannot be covered comprehensively in a brief introduction. Since the late 1960s, for example, the southern regions around Zinder and Maradi have experienced a high population growth and increase in population density (Mortimore \& Adams, 2001; Mohamadou \& Tremolieres, 2007) with a corresponding incentive for increased agricultural production. Agricultural land has expanded (Heasley \& Delehanty, 1996; Batterbury et al., 1999; Amissah-Arthur, Mougenot \& Loireau, 2000) and it is assessed that almost all arable land has been under cultivation here for the last three decades (Mortimore \& Adams, 2001). According to Mounkaila (2002), however, field expansion still takes place in an eastern direction in the northern Zinder department (central Niger). Around Niamey, it has been estimated that $90 \%$ of available land has been brought under cultivation (Saqalli, 2008).

Field expansions are, in part, governed by national rules. Since 1961, a politically determined pastoral zone has been established in Niger (Figure 1). In this zone, agricultural activities other than grazing and the holding of private property are prohibited. Traditionally, and consolidated by law since 1997 (decree No. 97-007 of 10 January 1997), a number of 'pockets' of pasture land and cattle corridors exist in the agricultural zone south of the pastoral zone (Lund, 1998) to enable pastoralists to pass through the otherwise agriculturally dominated areas. Pastoralists typically dwell in the southern agricultural zone during the dry season, and perform transhumance to the northern grazing areas during the rainy season. The traditional crop-livestock interaction in the zone south of the cultivation limit is important because it enables a coupling between the arable and the pastoral land uses, based on the exchange of ecological services such as cereals, manure, and stubble grazing. The severe droughts of the 1970s and 1980s transformed, however, this crop-livestock system profoundly (Thebaud, 1996). Manuring contracts became scarce as farmers increasingly used crop residues for their own livestock to make ends meet (Banoin \& Guenguant, 1999; Turner, 1999; Thebaud \& Batterbury, 2001; Osbahr \& Allan, 2003). Transhumance during the severe droughts was directed further south compared to the period before, and was performed mainly in the dry season (Boutrais, 2007) as herders were not able to secure enough feed for their cattle in the northern 
pastoral zone, or in the agricultural zones immediately to the south. After the period of droughts, improved veterinary techniques (better ways of protecting of cattle from parasites in the more humid southern areas) and regular political unrest in the north of the country led to a consolidation of this dry-season southward route (Augusseau, Cheylan, \& Liehoun, 2006; Boutrais, 2007), in spite of apparent weaknesses with regard to the formal recognition of pastoral land use and informal management arrangements such as water rights in the 1997 legal framework (Thebaud \& Batterbury, 2001).

The pastoral legal framework is interrelated with wider efforts to regulate private land tenure, the key piece of legislation being the Code Rural, adopted in 1994 and still being implemented. Aimed at translating supposedly unclear customary rights into clear tenure rights, the effect of the Code is, however, a (re)emergence of disputes and conflicts over rights among users and a scramble for land (Lavigne-Delville, Toulmin, Colin, \& Chaveau, 2001; Benjaminsen, Holden, Lund, \& Sjaastad, 2009). Secondary right holders such as women, pastoralists, and recent settlers are often excluded from formal rights. The high costs involved in obtaining a formal title, and the institutional incapacity of local governments to hand out these titles, have been driving land users to local power holders (local chiefs), creating a de facto legal pluralism (Benjaminsen et al., 2009; Bruce \& Knox, 2009).

Land use and land management in Niger have since independence been heavily influenced by international development assistance agendas. Triggered by the severe droughts in the 1970s and 1980s, a plethora of donors invested in Soil and Water Conservation (SWC) programs in the Sahel region, including Niger. Study tours were organized, on which farmers could observe successful techniques in neighboring regions or countries, leading to a high adoption of conservation techniques. As a consequence, many farmers in Niger have been protecting and managing natural regeneration on their cultivated fields since the 1980s and 1990s (Reij \& Smaling, 2008). According to the same authors, village committees for the protection of natural regeneration are vibrant social institutions, further contributing to the continued existence of practices. One of the side effects of the rehabilitation of degraded land with SWC has been the expansion of cultivated areas, and the creation of a market for barren land in the late 1990s (Reij \& Steeds, 2003). Structural adjustment and the resulting dramatic reduction of government spending on agricultural extension services and fertilizer programs during the this period might also have contributed to field expansions (Reardon et al., 1997).

\section{Data and Methods}

To identify dominant themes and major findings in land change research in Niger, we perform a meta-analysis style exploration of case studies presented in the Nigerien academic literature. This approach serves to explore the entire pool of acknowledged available material and provides a platform for a general overview of the focus and main outcomes of the Nigerien scholarly works.

\subsection{Definitions and Clarifications}

It is widely recognized that the terms land cover and land use are often used in the literature without recognition of the fundamental distinction between these terms (Eurostat, 2000). Moreover, systematic characterization of outcomes from land change science is complicated by the fact that researchers are still striving to refine theories that support analyses of causes and consequences of land system changes (e.g. Hersperger, Gennaio, Verburg \& Burgi, 2010; Reenberg, Rasmussen, \& Nielsen, 2012). Land change science has recently made conceptual advances in relation to driving forces of change (e.g. GLP, 2005; Lambin \& Geist, 2006; Turner, Lambin \& Reenberg, 2007; Seto et al., 2012). In the present context, we will limit the exploration of the published research to deal with the presentation of the empirical outcomes describing land changes. For this purpose, the issue of interest, 'Land change', is used in a broad sense of the notion, i.e. it refers to any investigation of observed or mapped change of the land system, including issues such as land use and land cover, agricultural and pastoral practices (extensification, intensification, new technologies, herd composition, etc.), agricultural expansion or contraction, land transactions, land fragmentation, and the appropriation of space.

A 'meta-analysis style' of analysis here refers to a systematic approach to investigate patterns across a set of published studies (Rudel, 2008). Meta-analyses offer an approach for a 'study of studies' or a means to provide a valuable "periodic collecting, evaluating, and integrating of scholarship in order to bring coherence and perspective to a problem area" (Cooper \& Hedges, 1994; Rudel, 2008). Doing a meta-analysis presumes a reasonable persistency of research focus, as defined by the research questions addressed by the research community. Rudel (2008) underlines that, in order to carry out insightful and credible meta-analyses, it is imperative to address a set of recurring questions about (1) case study selection, (2) coding procedures, and (3) variable selection. Some of the most successful meta-analyses (e.g. Geist \& Lambin, 2001) rely on a relatively large pool of case studies, which improves the significance of the results. Yet, the methodology may also be helpful to support a systematic screening of more limited material, as the current analysis attempts to provide. 


\subsection{Data Collection}

To be included in the database for the present exploration, a case study 1) has to present an analysis of land use/land cover change over time in Niger, and 2) has to be presented in a scientific publication and authored by Nigerien researchers. A study is perceived as an analysis of land change if it includes a description of observed and/or measured changes of the land system, a description of the causes of this change (both immediate and underlying), and preferably also a description of other concomitant changes observed. One scientific publication can contain several different case studies. These are considered as individual cases and analyzed as such if the cases presented can be differentiated in terms of geographical location or time period.

In composing the database, the aim is to collect all Nigerien academic publications on land change published since independence (i.e. since 1960). The identification of the scientific publications was conducted as a systematic search in digital databases, supplemented by visits to various libraries across Niger, in recognition of the fact that many local research publications are not digitally available.

\subsection{Variable Identification and Case Coding}

The first step in the meta-analysis consolidates a set of descriptive variables that can characterize the findings of the case study. The variable identification follows from an iterative process. In the first round of exploration, each case study in the database is screened with respect to the described a) land changes, b) other significant changes in the human-environment system, and c) identified causal factors of changes. The individual descriptions were organized under two broad categories: observed changes and causal explanations, which can be further subdivided into 'land use and pastoral system changes' and 'other observed significant changes in the human-environment system', and 'immediate causes leading to changes' and 'underlying, slower evolving causes of changes', respectively. The distinction between immediate and underlying causes of change is based on temporal proximity to the observed land changes and on the abruptness of the cause. For example, drought is perceived as an immediate cause, whereas a general worsening of climatic conditions is considered an underlying cause. Similarly, the immigration of new cultivators is seen as an immediate cause and gradual population increase as an underlying cause. After this initial screening, a second step aims at regrouping similar descriptions to form a smaller set of descriptive variables. Since the aim of the meta-analysis is to provide a general overview, a compromise has to be made on the level of detail of the descriptive variables that characterize the studies. Following this, all case studies are revisited and coded by use of the descriptive variables. In this last round, the labels of the descriptive variables are adjusted to reflect the closest possible match to the descriptions provided across all the papers (for example, the variable labeled 'expansion of cultivated areas' is refined to 'expansion of cultivated areas during the dry season'). Finally, the descriptive variables are coded as binary observations for each case as either present or absent.

\subsection{Analytical Approaches}

The total pool of Nigerien land change studies is scrutinized using three distinct methods (see Table 1). First, the case studies are characterized in terms of publication year; the time period considered, and the geographical location of the study. Second, aggregate information about the thematic priorities of the case studies is derived, employing a frequency analysis of the established matrix of descriptive variables. For each change variable (i.e. agricultural system, conservation, tenure, and other change) the frequency of occurrence across the case studies is calculated. In addition, the frequency of the causal variables (both immediate and underlying causes) is recorded. In order to explore a potential shift in the causal explanations and the thematic priorities over time, the frequency of occurrence of each of the descriptive variables is recorded relative to the time period in which the study was published. 
Table 1. Overview of the methods used to explore the Nigerien case studies

\begin{tabular}{|c|c|c|c|}
\hline Method & Description & Aim & Outcome \\
\hline \multirow[t]{2}{*}{1} & $\begin{array}{l}\text { Visualisation of the case studies } \\
\text { - time of publication } \\
\text { - length of observation period }\end{array}$ & Characterise the case studies & $\begin{array}{l}\text { Timeline with publication dates } \\
\text { and observation time for each of } \\
\text { the studies (Figure 1). }\end{array}$ \\
\hline & - geographical location & & $\begin{array}{l}\text { Country map with exact location } \\
\text { of the study sites (Figure } 2 \text { ). }\end{array}$ \\
\hline \multirow[t]{4}{*}{2} & Frequency analysis of generic variables & $\begin{array}{l}\text { Characterise the content of } \\
\text { case studies }\end{array}$ & \\
\hline & $\begin{array}{l}\text { Occurrence of each identified } \\
\text { - land system change } \\
\text { - pastoralist change } \\
\text { - other significant change }\end{array}$ & Identify thematic priorities & $\begin{array}{l}\text { Description of the thematic } \\
\text { priorities of the case studies }\end{array}$ \\
\hline & $\begin{array}{l}\text { Frequency of each of the causal } \\
\text { variables (both immediate and } \\
\text { underlying causes) }\end{array}$ & $\begin{array}{l}\text { Understanding of the } \\
\text { theoretical framing of the } \\
\text { studies }\end{array}$ & $\begin{array}{l}\text { Description of the presented } \\
\text { causes of land system change in } \\
\text { the case studies }\end{array}$ \\
\hline & $\begin{array}{l}\text { Time period in which the studies are } \\
\text { published }\end{array}$ & $\begin{array}{l}\text { Account for a potential shift } \\
\text { in focus of the thematic } \\
\text { priorities and theoretical } \\
\text { framing over time }\end{array}$ & $\begin{array}{l}\text { Description of the change over } \\
\text { time }\end{array}$ \\
\hline 3 & $\begin{array}{l}\text { Hierarchical cluster analysis of the } \\
\text { established matrix of variables }\end{array}$ & $\begin{array}{l}\text { Identify potential dominant } \\
\text { discursive profiles in the pool } \\
\text { of case studies }\end{array}$ & Identification of discourses \\
\hline
\end{tabular}

Third, a hierarchical cluster analysis (Ward's linkage) is used to find patterns of variables that identify potential dominant discursive profiles (i.e. a form of storyline that several case studies have in common). The cluster analysis systematically compares case studies with respect to the combination of observed changes and identified causes and enables classification of case studies on the basis of their (dis)similarity (i.e. classification of cases that have the same or similar land system changes and that associate similar causal factors to them).

To control for a range of obvious biases, we examine their distribution across the final cluster groups. Three factors are considered important in potentially causing a bias of the discursive trends: a) the discipline of the lead author(s), b) the affiliation of the publication, and c) geographical location (Rudel, 2008). Authors' disciplines might influence how they observe different land system changes, causal factors, or the thematic focus on the whole. Hence, the variation between geographers, agronomists, biologists, etc. is explored by means of a simple frequency count. The affiliation of the publication can be crucial to understand its emphasis. Each study was therefore coded according to the journal or larger project it belonged to. Finally, we distinguished case studies according to the administrative region in which the study sites were located.

\section{Results}

The following section presents the outcome of the analysis, in terms of a) where and when research had been conducted, b) the main observations and findings, c) dominating research questions and thematic priorities, d) the changing priorities and explanatory frameworks of the studies over time, and e) discursive trends in Nigerien land system change research of the last two decades.

\subsection{Overview of the Case Studies}

The final database contains 37 case studies published in 13 sources (books, journals, annals, etc.) and written by 17 different first authors, the majority of them geographers (70\%) (Table 2). We found only one academic study before 1990. Most of the case studies were published in the period 2000-2010. Table 2 suggests that earlier studies - up to the year 2000 - describe changes between the early 1960s and the time of publication. Post-2000 studies mainly describe land system changes from the 1970s onwards. Many case studies focus on recent observations made at the end of the observation period, i.e. at the time just before publication, but often describe in their analysis previous changes and causal factors during the entire observation period. Case studies 6, 7, 9, and 10 remain vague about the start of their observation period (as indicated in a lighter color). 
Table 2. List of the selected case studies with the name and discipline of the first authors and the time period covered

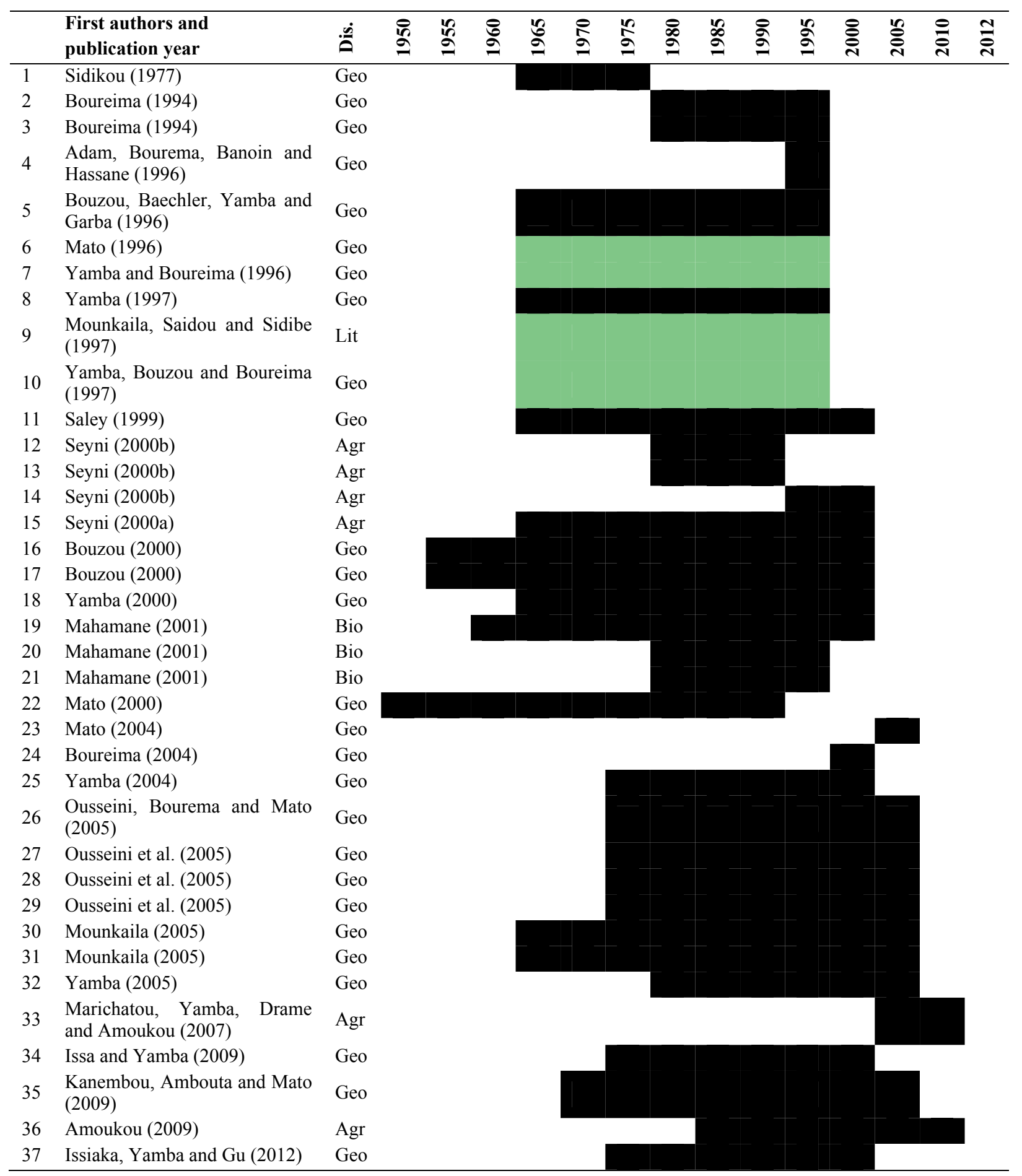

The case studies originate from 23 locations in the regions of Tillabery, Dosso, Maradi, Zinder, and Diffa (Figure 1). Agadez, the northernmost region in Niger, is not represented. Sometimes case studies combine information from several field sites, for example from the three villages of Jiratawa, Magami, and Sharken Haoussa in southern Maradi, or from the villages of Winde-Bago and Doye-Bangou in Dosso (five case studies in all, each combining information from both villages). This reduces the number of 'actual' study sites to 20 . 


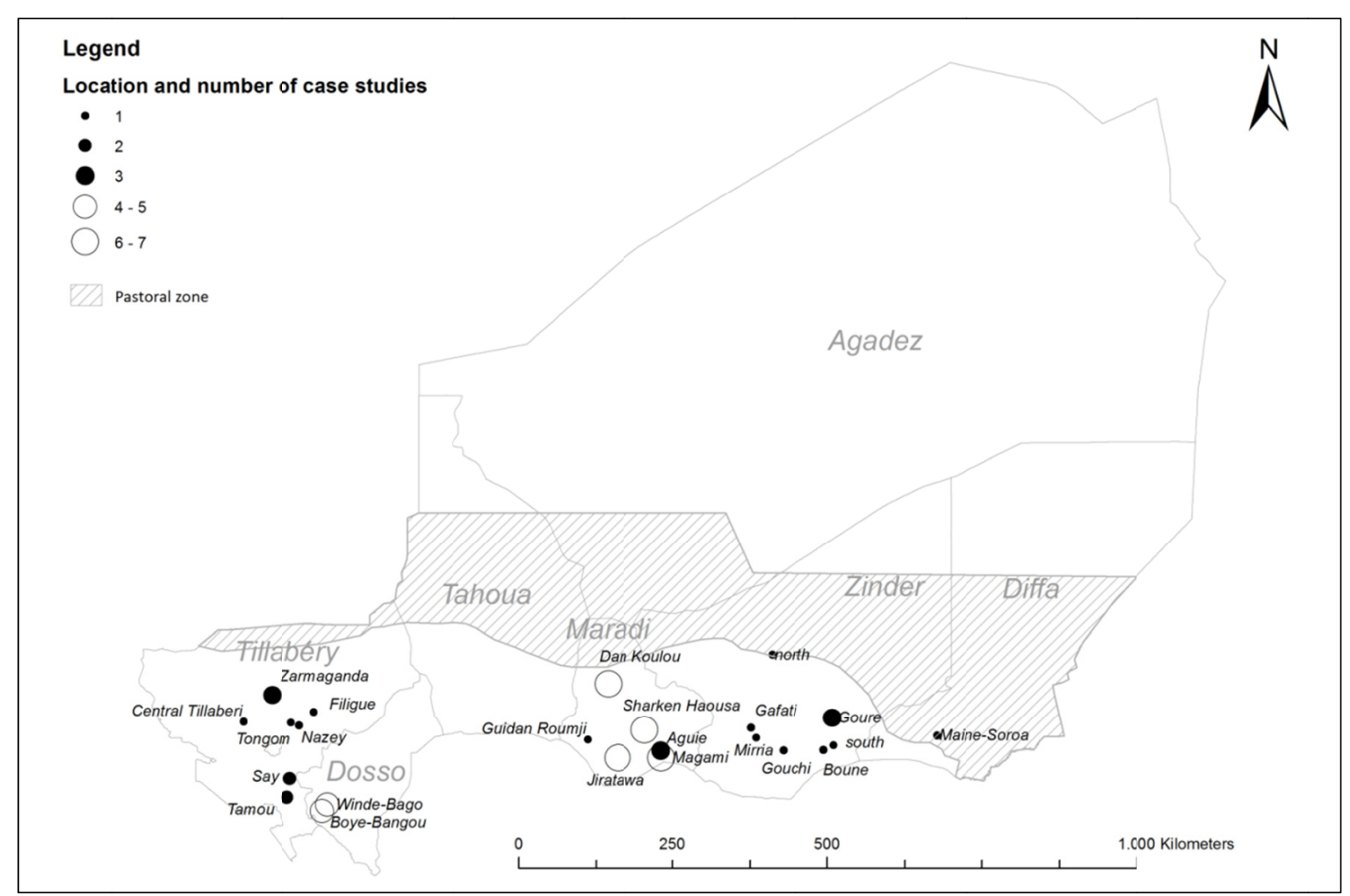

Figure 1. Location of the case studies

The geographic location of the case studies determines their focus of interest. In fact, studies located in the south of Tillaberi (Say and Tamou) and in the south of Zinder (Gouchi, Gafati, and Boune) (six studies in all) observe very different challenges related to land system changes as compared to the other studies in the database. Unlike elsewhere in Niger, these specific areas have recently been opened up for cultivation and have experienced an influx of (new) cultivators. Four of the cases report an expansion of cultivated areas and three (50\%) of the cases report land transactions (sales). Moreover, all these cases observe severe contemporary land degradation as the outcome of human activity. The main immediate cause for degradation proposed is overexploitation due to the immigration of new cultivators into the area (all cases) and (new) market opportunities (five cases out of six) (the sites in Tillaberi are located close to Niamey). Weak (control) institutions and a culturally determined hospitality towards immigrants are identified as the predominant underlying causes of the observed degradation. Three of the cases furthermore mention that recent demographic pressure increasingly contributes to the already existing degradation.

Since the contextual conditions of these six cases are so specific, we analyze and discuss them separately from the remaining 31 cases, to which we turn our attention in the next section.

\subsection{Observed Land System Changes, Thematic Priorities and Causal Explanations}

The variable identification procedure finds six broad types of land system changes (Table 3). Close to 60 percent of the 31 case studies record an expansion of agricultural areas at the end of the observation period of the study. More than half of the studies record an intensification of agriculture. Conservation efforts undertaken by the local population are mentioned in half of the studies and 42 percent of the cases report land tenure changes. Overall, very few studies report on pastoralist system changes. 
Table 3. Frequency of the broad types of changes observed in the Nigerien land change studies

\begin{tabular}{|c|c|c|c|c|c|c|c|c|c|c|c|c|}
\hline \multirow{3}{*}{$\mathrm{N}$} & \multirow{3}{*}{$\begin{array}{l}\text { Case studies } \\
\text { First authors and } \\
\text { publication year }\end{array}$} & \multicolumn{11}{|c|}{ Types of observed changes } \\
\hline & & \multirow[t]{2}{*}{$\begin{array}{c}\text { Expansio } \\
-n\end{array}$} & \multirow[t]{2}{*}{$\begin{array}{l}\text { Degrada } \\
\text {-tion }\end{array}$} & \multirow[t]{2}{*}{$\begin{array}{l}\text { Intensifi } \\
\text {-cation }\end{array}$} & \multirow[t]{2}{*}{$\begin{array}{c}\text { Conserv } \\
\text {-ation }\end{array}$} & \multirow[t]{2}{*}{ Tenure } & \multirow{2}{*}{$\begin{array}{c}\text { Pastorali } \\
\text {-st } \\
\text { system } \\
\text { changes }\end{array}$} & \multicolumn{5}{|c|}{$\begin{array}{l}\text { Concurrent } \\
\text { changes }\end{array}$} \\
\hline & & & & & & & & $\mathbf{M}$ & $\mathrm{T}$ & $\mathbf{E}$ & $\mathbf{S}$ & $\mathrm{C}$ \\
\hline 1 & Sidikou (1977) & $\mathrm{x}$ & & $\mathrm{x}$ & & & & $\mathrm{x}$ & & & $\mathrm{x}$ & \\
\hline 2 & Boureima (1994) & $\mathrm{x}$ & $\mathrm{x}$ & & & $\mathrm{x}$ & & & & & $\mathrm{x}$ & $\mathrm{x}$ \\
\hline 3 & Boureima (1994) & & & & & & & $\mathrm{x}$ & & & & \\
\hline 4 & Adam et al. (1996) & & & $\mathrm{x}$ & & & & & & & & \\
\hline 5 & Bouzou et al. (1996) & $\mathrm{x}$ & & $\mathrm{x}$ & & & & & & & & $\mathrm{x}$ \\
\hline 6 & Mato (1996) & & & $\mathrm{x}$ & & & & & $\mathrm{x}$ & $\mathrm{x}$ & & \\
\hline 7 & Yamba and Boureima & & & $\mathrm{x}$ & & & $\mathrm{x}$ & & & $\mathrm{x}$ & & \\
\hline 8 & Yamba (1997) & $\mathrm{x}$ & & $\mathrm{x}$ & $\mathrm{x}$ & $\mathrm{x}$ & & & & & $\mathrm{x}$ & \\
\hline 9 & Mounkaila et al. (1997) & & & $\mathrm{x}$ & $\mathrm{x}$ & & $\mathrm{x}$ & & & & $\mathrm{x}$ & \\
\hline 10 & Yamba et al. (1997) & $\mathrm{x}$ & & $\mathrm{x}$ & $\mathrm{x}$ & & & & & & & \\
\hline 11 & Saley (1999) & $\mathrm{x}$ & & $\mathrm{x}$ & & & & $\mathrm{x}$ & & $\mathrm{x}$ & & \\
\hline 12 & Seyni (2000b) & $\mathrm{x}$ & & $\mathrm{x}$ & & & & & & & & \\
\hline 13 & Seyni (2000b) & & & $\mathrm{x}$ & & $\mathrm{x}$ & & $\mathrm{x}$ & & & & \\
\hline 14 & Seyni (2000b) & $\mathrm{x}$ & & & & $\mathrm{x}$ & & $\mathrm{x}$ & & & & \\
\hline 15 & Seyni (2000a) & $\mathrm{x}$ & & $\mathrm{x}$ & & & & & $\mathrm{x}$ & $\mathrm{x}$ & & \\
\hline 16 & Bouzou (2000) & & & $\mathrm{x}$ & $\mathrm{x}$ & $\mathrm{x}$ & & & $\mathrm{x}$ & & $\mathrm{x}$ & \\
\hline 17 & Bouzou (2000) & $\mathrm{x}$ & & & $\mathrm{x}$ & $\mathrm{x}$ & & & & & $\mathrm{x}$ & \\
\hline 18 & Yamba (2000) & & & & $\mathrm{x}$ & $\mathrm{x}$ & & & & & $\mathrm{x}$ & $\mathrm{x}$ \\
\hline 19 & Mahamane (2001) & $\mathrm{x}$ & & & $\mathrm{x}$ & $\mathrm{x}$ & & & & & & \\
\hline 20 & Mahamane (2001) & $\mathrm{x}$ & & & $\mathrm{x}$ & & & & & & & \\
\hline 21 & Mahamane (2001) & $\mathrm{x}$ & & & & & & & & & & \\
\hline 22 & Mato (2000) & & & $\mathrm{x}$ & & & & & & & & \\
\hline 23 & Mato (2004) & $\mathrm{x}$ & & & & $\mathrm{x}$ & & & & & $\mathrm{x}$ & $\mathrm{x}$ \\
\hline 24 & Boureima (2004) & & & $\mathrm{x}$ & $\mathrm{x}$ & $\mathrm{x}$ & $\mathrm{x}$ & $\mathrm{x}$ & & & $\mathrm{x}$ & $\mathrm{x}$ \\
\hline 25 & Yamba (2004) & & & & $\mathrm{x}$ & $\mathrm{x}$ & & & $\mathrm{x}$ & & $\mathrm{x}$ & $\mathrm{x}$ \\
\hline 26 & Ousseini et al. (2005) & $\mathrm{x}$ & $\mathrm{x}$ & & & & & & & $\mathrm{x}$ & $\mathrm{x}$ & $\mathrm{x}$ \\
\hline 27 & Ousseini et al. (2005) & $\mathrm{x}$ & $\mathrm{x}$ & & $\mathrm{x}$ & $\mathrm{x}$ & $\mathrm{x}$ & & & & $\mathrm{x}$ & \\
\hline 28 & Ousseini et al. (2005) & $\mathrm{x}$ & $\mathrm{x}$ & & $\mathrm{x}$ & & & & & & & \\
\hline 29 & Ousseini et al. (2005) & $\mathrm{x}$ & $\mathrm{x}$ & & $\mathrm{x}$ & & & & & & & \\
\hline 30 & Mounkaila (2005) & & & & $\mathrm{x}$ & & & $\mathrm{x}$ & & & & \\
\hline 31 & Mounkaila (2005) & $\mathrm{x}$ & $\mathrm{x}$ & & $\mathrm{x}$ & $\mathrm{x}$ & & $\mathrm{x}$ & & $\mathrm{x}$ & $\mathrm{x}$ & \\
\hline 32 & Yamba (2005) & $\mathrm{x}$ & & & & $\mathrm{x}$ & & $\mathrm{x}$ & & $\mathrm{X}$ & $\mathrm{x}$ & \\
\hline 33 & Marichatou et al. (2007) & & & & $\mathrm{x}$ & $\mathrm{x}$ & $\mathrm{x}$ & & $\mathrm{x}$ & & $\mathrm{x}$ & \\
\hline 34 & Issa and Yamba (2009) & $\mathrm{x}$ & & $\mathrm{x}$ & $\mathrm{x}$ & & $\mathrm{x}$ & $\mathrm{x}$ & & & & \\
\hline 35 & Kanembou et al. (2009) & $\mathrm{x}$ & & & $\mathrm{x}$ & & & & & & & \\
\hline 36 & Amoukou (2009) & $\mathrm{x}$ & & $\mathrm{x}$ & $\mathrm{x}$ & $\mathrm{x}$ & $\mathrm{x}$ & $\mathrm{x}$ & $\mathrm{x}$ & $\mathrm{x}$ & $\mathrm{x}$ & $\mathrm{x}$ \\
\hline 37 & Issiaka et al. (2012) & $\mathrm{x}$ & & $\mathrm{x}$ & & & & & $\mathrm{x}$ & $\mathrm{x}$ & $\mathrm{x}$ & \\
\hline & Total $(n=37)$ & 24 & 6 & 18 & 19 & 16 & 7 & & & $27 \mathrm{a}$ & & \\
\hline
\end{tabular}

$\mathrm{M}=$ Mobility; $\mathrm{T}=$ Technical changes; $\mathrm{E}=$ Economic changes; $\mathrm{S}=$ Social changes; $\mathrm{C}=$ Conflict 
The broad types of change are subdivided into more specific changes (Table 4). Agricultural expansion, for example, assembles 'actual field area expansion' and 'agricultural colonization of valley bottoms'. Actually, field expansion is the leading observed land change in the database of 31 case studies. With regard to agricultural intensification, the use of fertilizers is most frequently mentioned, followed by the introduction of new crop varieties and dry season (horticulture) production. Conservation efforts are represented by soil conservation and forest regeneration efforts. Eight of the 31 studies report on land sales and seven cases report on increased land fragmentation. Four cases observe a tendency of appropriation of space (i.e. individuals claiming land for their exclusive use by putting up fences). The few studies dealing with pastoralist systems mention changes in herd composition, in feed stocks and in transhumance movements.

Table 4. Variables representing more specific observed landsystem and concurrent changes as described in the 31 case studies

\begin{tabular}{lllcc}
\hline $\begin{array}{l}\text { Land system } \\
\text { changes observed }\end{array}$ & $\begin{array}{l}\text { Broad } \\
\text { subdivision of } \\
\text { observed change }\end{array}$ & Specific variable & Frequency & $\begin{array}{c}\text { Percent of } \\
\text { cases }\end{array}$ \\
\hline Agricultural system & Expansion & Field area expansion & 17 & 54.8 \\
& & Valley bottoms used & 4 & 12.9 \\
& Intensification & Fertilisers & 12 & 38.7 \\
& & Counter season production & 8 & 25.8 \\
& & New crops & 10 & 32.3 \\
Conservation & Soil conservation & 12 & 38.7 \\
& & Forestation/Natural regeneration & 11 & 35.5 \\
Tenure & Land fragmentation & 7 & 22.6 \\
& & Land sales & 8 & 25.8 \\
Pastoralist system & Appropriation of space & 4 & 12.9 \\
& & Unspecified change & 3 & 9.7 \\
& & Transhumance & 3 & 9.7 \\
& & Herd composition & 4 & 12.9 \\
\hline Concurrent changes & & Feedstock & 2 & 6.5 \\
\hline observed & Intensification & Specific variable & & \\
\hline Mobility & & Outmigration & 10 & 32.3 \\
Technical changes & & New agricultural tools and techniques & 7 & 22.6 \\
Economic changes & & Emergence of paid labour & 4 & 12.9 \\
& & Income diversification/Cash seeking & 5 & 16.1 \\
Social change & & Emergence of new land users & 4 & 12.9 \\
& & Change in behaviour of local population & 12 & 38.7 \\
Conflicts & & Individualisation & 5 & 16.1 \\
\hline & & Ehange in traditional land use management & 5 & 16.1 \\
& & & 6.9 & 19.4 \\
\hline
\end{tabular}

Other significant changes in the human-environment system have a prominent place in the publications (Table 3 ). The two most frequently observed concurrent changes are mobility and changes in the behavior of the local population (Table 4). The case studies furthermore report on the emergence of new agricultural techniques, of paid labor opportunities, and of a cash-seeking orientation of the local population. Many studies mention social change. Apart from the behavioral changes of the local population, researchers observe the emergence of new groups of land users such as women and youngsters, an increased 'individualization' of land use, and a change away from the traditional management of natural resources. Finally, six studies also observe emerging resource conflicts. 
With respect to the causes of the observed changes, the cases point to five immediate causes of change and six underlying causes (Table 5). Degradation of natural resources and degradation of cultivated land are the most frequently observed immediate causes of change. These are followed by 'overexploitation of natural resources' mentioned in well over a third of the cases. Other immediate causes are the emergence of new markets, a recent period of drought, cash crops competing for land, immigration of new cultivators, and unfavorable economic conditions.

Table 5. Variables representing immediate and underlying causes of change, as mentioned in the post-degradation discourse case studies

\begin{tabular}{|c|c|c|c|c|}
\hline $\begin{array}{l}\text { Immediate conditions } \\
\text { leading to change }\end{array}$ & $\begin{array}{l}\text { Broad } \\
\text { subdivision of } \\
\text { observed change }\end{array}$ & Specific variable & Frequency & $\begin{array}{l}\text { Percent } \\
\text { of cases }\end{array}$ \\
\hline \multirow[t]{2}{*}{ Degradation } & & Natural resource degradation & 16 & 51.6 \\
\hline & & Cultivated land degradation & 18 & 58.1 \\
\hline Overexploitation & & Overexploitation & 14 & 45.2 \\
\hline Drought & & Recent drought & 4 & 12.9 \\
\hline \multirow[t]{2}{*}{ Land acclamation } & & Cash crops claiming land & 2 & 6.5 \\
\hline & & Immigration of new cultivators & 2 & 6.5 \\
\hline \multirow[t]{2}{*}{ Economic conditions } & Favourable & $\begin{array}{l}\text { New market opportunities due to e.g. urban } \\
\text { development }\end{array}$ & 6 & 19.4 \\
\hline & Unfavourable & Unfavourable economic conditions & 2 & 6.5 \\
\hline $\begin{array}{l}\text { Underlying causes of } \\
\text { change }\end{array}$ & & Specific variable & & \\
\hline \multirow[t]{2}{*}{ Institutional factors } & & Weak support institutions & 6 & 19.4 \\
\hline & & Absence of control mechanism & 1 & 3.2 \\
\hline Climatic actors & & Unfavourable evolution of climatic conditions & 25 & 80.6 \\
\hline Inherent soil quality & & Low soil fertility/quality & 9 & 29 \\
\hline Demographic factors & & Demographic pressure/Population growth & 20 & 64.5 \\
\hline Economic factors & & Monetization of the economy & 7 & 22.6 \\
\hline \multirow[t]{2}{*}{ Social factors } & & Social relations of agricultural loans and gifts & 3 & 9.7 \\
\hline & & Cultural beliefs and traditional land use & 3 & 9.7 \\
\hline
\end{tabular}

An unfavorable evolution of climatic factors since the droughts of the $1970 \mathrm{~s}$ is thought to be the dominant underlying cause of change, mentioned in 80 percent of the cases (Table 5, bottom part). Then follow increased demographic pressure, institutional factors, a low inherent soil quality, monetization of the economy, traditional belief systems, and social relations systems.

The thematic priorities vary over time. Several topics discussed in the case studies appear to be dependent upon the time of the publication. Land transactions, individualization, appropriation of space, and changes in traditional management systems, for example, are only mentioned from 2000 and onwards. This may be the result of a profound change in the traditional land transfer systems that took place from 2000, away from inheritance, 'social' loans, and gifts. The emerging story from the case studies is that it has become economically more interesting to sell land, also for those that are considered disadvantaged in the traditional system (by being attributed small plots of land).

The majority of the 31 cases examined (58\% or 18 cases) take point of departure in a 'disequilibrium' apprehension - most of these cases actually mention the word 'déséquilibre'. The start of the perceived imbalance between the natural resource stock and human exploitation hereof is often postulated to be at the beginning of the $20^{\text {th }}$ century, and believed to have been aggravated by the droughts of the 1970 and 1980 s. This mind-set typically leads the case studies to focus on land use/ land management strategies adopted by the local population as a point of departure to investigate this disequilibrium and the corresponding adaptive change. In fact, over 60 percent of the cases (19 observations) explicitly mention the word 'adaptation'. 


\subsection{Cluster Analysis: Discursive Profiles}

In order to tease out dominant discourses in the Nigerien academic land change literature, patterns across the pool of case studies are identified, and their similarity in terms of observed changes and corresponding causes is explored. The entire pool of 37 cases is subjected to a hierarchical cluster analysis. The classification tree (or dendrogram) shows the groups of case studies (x-axis) and the relative distance (dissimilarity) between the different groups at various stages of the grouping procedure (y-axis) (Figure 2). In step one, three groups are distinguished with regard to land system changes and their causes (Figure 2 and Table 6). One group represents a degradation discourse (group 3, Table 6). This group consists of the six agricultural colonization cases in the southern parts of Tillabere and Zinder, which were pointed out as specific cases earlier. Apart from focusing on degradation, all these cases observe expansion of agricultural areas, explained as a result of land claims by immigrating cultivators who were attracted by the economic opportunities such as nearby markets (e.g. Niamey) to sell produce. The two identified underlying factors for the degradation are weak official regulatory institutions and a local culture, traditionally welcoming towards immigrants by allocating them a parcel of land for agricultural use.

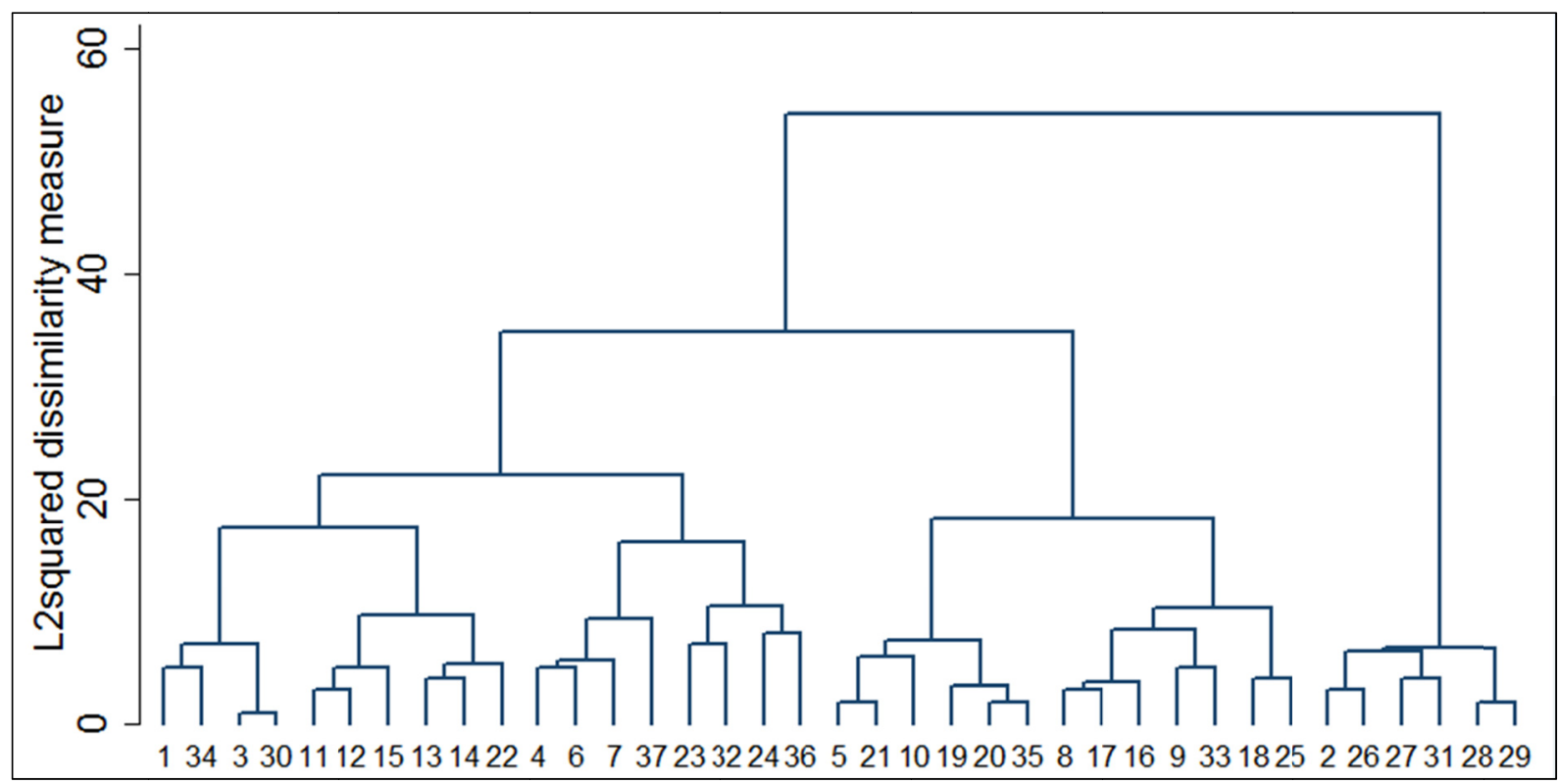

Figure 2. Full dendrogram resulting from the cluster analysis 


\begin{tabular}{|lccc|}
\hline \multicolumn{3}{|c|}{ Group variable } \\
\hline & Characteristics of the three main cluster groups \\
\hline Observations (\% of cases) & $\mathbf{1}$ & $\mathbf{2}$ & $\mathbf{3}$ \\
\hline Land system changes & & & \\
Expansion & 56 & 62 & 100 \\
Intensification & 72 & 38 & 0 \\
Conservation & 17 & 85 & 0 \\
Tenure & 33 & 54 & 50 \\
Degradation & 0 & 0 & 100 \\
Pastoralist system & 22 & 15 & 17 \\
Concurrent changes & & & \\
Outmigration & 56 & 0 & 17 \\
Technological change & 22 & 23 & 0 \\
Economic change & 39 & 0 & 33 \\
Social change & 33 & 54 & 67 \\
Ressource conflicts & 17 & 23 & 33 \\
Immediate conditions & & & \\
Degradation & 56 & 92 & 0 \\
Overexploitation & 17 & 85 & 0 \\
Drought & 22 & 0 & 0 \\
Land acclamation & 6 & 15 & 100 \\
Economic conditions & 22 & 31 & 83 \\
Underlying drivers & & & \\
Institutional factors & 22 & 23 & 83 \\
Climate factors & 78 & 85 & 17 \\
Biophysical factors & 44 & 8 & 0 \\
Demographic growth \& pressure & 39 & 100 & 50 \\
Monetisation & 22 & 23 & 0 \\
Social system & 17 & 15 & 100 \\
\hline Total number of cases & & & 6 \\
\hline
\end{tabular}

The remaining groups reflect two additional human-environment discourses: an intensification discourse and an expansion-conservation discourse. The cases grouped under intensification discourse in general terms describe how a worsening of the climate leads to agricultural intensification (group 1, Table 6). However, the picture presented in the case studies contains more nuances and there is still a considerable dissimilarity in terms of other significant (land use) changes observed between the cases in this group. In order to examine this in more detail the subordinate (lower lying, Figure 2) cluster groups are investigated. Three dominant sub-discourses seem to appear. Only one of them observes agricultural intensification for all cases (10 cases, groups 2 and 3 in Table 7). This sub-discourse may be described as a pure intensification discourse: i.e. it accentuates how a general worsening of the climate combines with an increasing monetization of the economy and emerging paid labor opportunities, which triggers households to intensify their agricultural production. The second sub-discourse (group 1 in Table 7), the mobility discourse, actually suggests that a period of drought, in a context of a worsening climate and a general degradation of the natural and agricultural resources, causes populations to emigrate. In some cases, fertilizers and new crop varieties allow an intensification of the remaining agriculture. The third sub-discourse (group 4 in Table 7) can be characterized as an individualization discourse. Here, problems related to natural and agricultural resource degradation on inherently poor soils lead to an expansion of agricultural surfaces; importantly, this frequently takes place through a change in tenure regimes. The case studies in this group emphasize that an increased individualization and the emergence of new groups of land 
users (women, for example) alter the general behavior of the local population with regard to their land management system. This leads to an increased fragmentation of land, land sales, resource conflicts, and outmigration.

\begin{tabular}{|c|c|c|c|c|c|c|c|}
\hline \multirow[b]{3}{*}{ Observations (\% of cases) } & \multicolumn{7}{|c|}{ Group variable } \\
\hline & \multicolumn{4}{|c|}{1} & \multicolumn{2}{|c|}{2} & \multirow{2}{*}{$\begin{array}{l}3 \\
7\end{array}$} \\
\hline & 1 & 2 & 3 & 4 & 5 & 6 & \\
\hline \multicolumn{8}{|l|}{ Land use changes } \\
\hline Expansion & 50 & 67 & 25 & 75 & 100 & 29 & 100 \\
\hline Intensification & 50 & 83 & 100 & 50 & 33 & 43 & 0 \\
\hline Conservation & 25 & 0 & 0 & 50 & 67 & 100 & 0 \\
\hline Tenure & 0 & 33 & 0 & 100 & 17 & 86 & 50 \\
\hline Degradation & 0 & 0 & 0 & 0 & 0 & 0 & 100 \\
\hline Pastoralist system & 25 & 0 & 25 & 50 & 0 & 29 & 17 \\
\hline \multicolumn{8}{|l|}{ Concurrent changes } \\
\hline Outmigration & 100 & 50 & 0 & 75 & 0 & 0 & 17 \\
\hline Technological change & 0 & 17 & 50 & 25 & 0 & 43 & 0 \\
\hline Economic change & 0 & 33 & 75 & 50 & 0 & 0 & 33 \\
\hline Social change & 25 & 0 & 25 & 100 & 0 & 100 & 67 \\
\hline Ressource conflicts & 0 & 0 & 0 & 75 & 17 & 29 & 33 \\
\hline \multicolumn{8}{|l|}{ Immediate conditions } \\
\hline Degradation & 100 & 0 & 75 & 75 & 100 & 86 & 0 \\
\hline Overexploitation & 0 & 0 & 50 & 25 & 67 & 100 & 0 \\
\hline Drought & 100 & 0 & 0 & 0 & 0 & 0 & 0 \\
\hline Land acclamation & 0 & 0 & 25 & 0 & 17 & 14 & 100 \\
\hline Economic conditions & 25 & 33 & 25 & 0 & 33 & 29 & 83 \\
\hline \multicolumn{8}{|l|}{ Underlying drivers } \\
\hline Institutional factors & 25 & 33 & 0 & 25 & 0 & 43 & 83 \\
\hline Climate factors & 100 & 83 & 75 & 50 & 100 & 71 & 17 \\
\hline Biophysical factors & 25 & 0 & 100 & 75 & 17 & 0 & 0 \\
\hline Demographic growth \& pressure & 0 & 50 & 50 & 50 & 100 & 100 & 50 \\
\hline Monetisation & 0 & 67 & 0 & 0 & 17 & 29 & 0 \\
\hline Social system & 0 & 0 & 50 & 25 & 17 & 14 & 100 \\
\hline Observations in group & 4 & 6 & 4 & 4 & 6 & 7 & 6 \\
\hline Case studies & $1,3,30,34$ & $11-15,22$ & $4,6,7,37$ & $23,24,32,36$ & $\begin{array}{c}5,10,19- \\
21,35\end{array}$ & $\begin{array}{c}8,9,16- \\
18,25,33\end{array}$ & $2,26-29,31$ \\
\hline
\end{tabular}

The expansion discourse sees the expansion of agricultural areas as a dominant feature (group 2, Table 6). It explains how field expansion is triggered by an overexploitation of natural and agricultural resources which, in turn, is driven by a combination of increasing population pressure and aggravated climatic conditions. However, also this group of case studies covers a range of more nuanced stories reporting on, for example, conservation efforts, tenure changes, and social change. A closer look at the cluster sub-groups reveals two sub-discourses: a pure expansion discourse and a conservation discourse (groups 5 and 6, respectively, in Table 7). In the latter, social changes, and in particular, changes in the traditional land management system, are reported to lead to the observed conservation efforts. However, the more recent studies in this group (those published from 2000 onwards) also see tenure related changes such as increased fragmentation, transaction, and appropriation of land as consequences of the general move away from traditional land management systems. 
The prominence of the discourses appears to have changed over time. The individualization discourse for example, appears only as of 2004. This might be because changes in tenure regimes, only observed after 2000, are a dominant feature of this discourse.

\section{Discussion}

\subsection{Underpinning Narratives and Thematic Interests}

As outlined in the introduction, Sahelian land change research has, since the 1970s, roughly evolved around three major narratives: desertification, dryland degradation, and climate change adaptation. The influence of these gradually changing, fundamental perspectives can to some extent be seen in the Nigerien scholarly work. However, it can be argued that the pool of case studies that has been identified for our exploration seems to be more influenced by the shifting priorities dominating the international development intervention, such as food aid, afforestation, and sustainable agricultural practices against desertification, or potential agro-technical advancements, such as soil conservation and natural vegetation regeneration, increased fertilizer use, and the adoption of new/enhanced crop varieties. The explanatory outlines presented in the Nigerien publications commonly treat recent human behavior as an attempt to regain an equilibrium that was disrupted by increasing population pressure and the resulting human over-exploitation of the natural resource base under a changing climate. By doing so in the long term, historical dynamics of human-environmental interactions remain poorly understood as does the alteration of the change processes. The temporal window of exploration is mainly in the order of magnitude of a hundred years, which leaves out considerations of the longer term perspectives of human-environmental interactions. While imagining the near past as an equilibrium situation, e.g. in relation to the human pressure on natural resources, may be important to understand the best ways to cope with the present challenges, it may be equally important to recognize that significant conditions may be changing so much in the long term that a perceived equilibrium cannot be regenerated. As stressed by Brooks (2012:93) it is important that the perception of land system changes in the Sahel is built on narratives of linked climatic, environmental, and societal changes that accommodate a variety of responses and outcomes and that are a more nuanced version of climate-induced collapse of specific societies.

\subsection{Observed (Land System) Changes}

The case studies present a surprisingly broad palette of changes. As saturation of potential cropland is a frequently mentioned challenge in environmental and agricultural policy documents, it is no surprise that it is a prominent theme in many of the studies. It seems, however, not to be systematically documented. The division of attention between the six types of land changes (expansion, degradation, intensification, conservation, tenure, and pastoral use) appears to be randomly determined by the research questions underpinning the respective studies, rather than aiming at a broader characterization of major trends in trajectories of change.

In thinking about trajectories of land change in the Sahel, it is important to recognize the coupling of land use and livelihood systems (e.g. Nielsen \& Reenberg, 2010; Rasmussen \& Reenberg, 2012). Much of the literature on Sahelian livelihoods deals with rural dwellers' diversification of activity portfolios (e.g. Barrett, Reardon \& Webb, 2001; Nielsen, D'haen \& Reenberg, 2012). Even though some of the Nigerien publications touch upon activity portfolios, transformations in livelihoods are not explicitly addressed. Moreover, the papers more often approach this from the perspective of changing opportunities in agriculture than from the perspective of emerging livelihood opportunities outside of agriculture.

\subsection{Causes of Change}

Most studies remain very vague in terms of when exactly change and adaptations came about. They first describe the general background and agro-environmental context of a process of land degradation, and then highlight the adaptive measure of the local population and resulting land use changes, but fail to clearly indicate cause-effect relationships.

The identification of immediate causes of change are highly influenced by the notions of environmental degradation; degradation of natural resources and cropland is, together with overexploitation of natural resources, the cause that is most frequently pointed out. Yet, economic and social factors are also important (emerging markets, immigration, economic conditions etc.). Climate and population pressure are identified as the most important underlying causes of change, but again, attention is also drawn to a range of other factors (soil fertility, social relations, traditional belief systems, etc.). In fact, the findings seem to portray the diversity and complexity of the change processes, rather than a simple chain of causal explanations. This does not undermine the narrative of a vulnerable and unsustainable land system, but it illustrates the need to consider and link societal and environmental perspectives in order to accommodate multiple and diverse outcomes. 


\subsection{Discursive Profiles}

As of 2004, however, studies suggest parallel trajectories of change. Both the individualization and the conservation discourse may indicate the start of a broadening of the research agenda toward changes in the traditional land transfer systems and the associated profound social changes. In this respect, the case studies reveal the profound influence that Niger's Code Rural has on rural land use and management. The ongoing struggle for land is documented as increased observations of land transactions, individualization, and appropriation of space in the case studies published since the 2000s. Although rarely explicitly mentioned, in many case studies, the Code is perceived to have a profound impact on local populations' attitude towards land.

Several case studies in the data pool for this research were written by the same first authors. However, the authors do not seem to lean toward a particular discourse. Similarly, little bias was observed in relation to the discipline of the first authors. The Nigerien research community on land change worked in cooperation with the Université de Bordeaux II (1980s) (five studies) and the Institut de Géographie de l'Université de Lausanne (IGUL) (seven studies) in Switzerland (late 1990s and 2000s). Many of the researchers were also involved in the Drylands Research initiative (late 1990s) (Drylands_Research, no date) (10 case studies). Case studies belonging to one of these initiatives showed a fairly even distribution across the different discourses, suggesting that no or very little bias had occurred at this level. Several different regions of Niger have been studied, yet there seems to be no discursive geographical bias.

\section{Conclusion}

Perhaps the most significant finding of our literature review is the general lack of scientific publications on land change in Niger. In fact, this is found to be true not only for Nigerien researchers but also for the wider international research community (see also van Vliet et al., 2013).

The value of national and international environmental policy documents for sustainable development depends critically on accurate knowledge about coupling of human actions and the environment. In this respect, there is a glaring need for more systematic documentation of the state as well as the dynamics of change of the land system, not least in Niger, which is one of the world's poorest nations with one of the fastest growing populations. Land here remains- an important resource to provide food for local people as well as other important ecosystem services. Hence, insight into ways to avoid overexploitation and unsustainable use is crucial.

In planning for future research needs, the current lack of systematic analysis of land system changes that reach beyond simplistic determinism should be recognized. Land system trajectories deserve to be systematically documented and fully understood as complex human-environmental systems. This implies developing narratives and models of linked societal and environmental change that move beyond preconceived causal explanations and allow for systematic exploration of deeper time dimensions of environmental causes as well as human agency.

\section{Acknowledgement}

The research presented was funded by a grant from the DANIDA-FFU, 09-001KU, and contributes to the ERC project Waterworlds. The study was part of the project: A region wide assessment of land system resilience and climate robustness in the agricultural frontline of Sahel (LASYRE).

\section{References}

Adam, T., Bourema, A., Banoin, M., \& Hassane, I. (1996). Analyse des contraintes de production agricole dans le terroir de Boye-Bangou (Boboye, Niger). Annales de l'universite Abdou Moumouni de Niamey, Theme agri-cultures en mutation Hors serie, 125-136.

Amissah-Arthur, A., Mougenot, B., \& Loireau, M. (2000). Assessing farmland dynamics and land degradation on Sahelian landscapes using remotely sensed and socioeconomic data. International Journal of Geographical Information Science, 14(6), 583-599. http://dx.doi.org/10.1080/136588100415756

Amoukou, I. (2009). Un village nigérien face au changement climatique. Stratégies locales d'adaptation au changement climatique dans une zone rurale du bassin du Niger. Autorite du Bassin du Niger, GTZ, Universite Abdou Moumouni de Niamey, Niamey.

Augusseau, X., Cheylan, J. P., \& Liehoun, E. (2006). Dynamiques territoriales de l'agropastoralisme en zone de migration: niveaux d'organisation et interactions. Cahiers d'études et de recherches francophones /Agricultures, 13, 488-494. 
Banoin, M., \& Guenguant, J. P. (1999). Les systèmes agraires traditionnels Nigeriens dans l'impasse face à la démographie. In C. Floret, \& R. Pontanier (Eds.), Jachères et systèmes agraires. CORAF/Union Européenne, Dakar. 1, 1-14.

Barrett, C. B., Reardon, T., \& Webb, P. (2001). Nonfarm income diversification and household livelihood strategies in rural Africa: concepts, dynamics, and policy implications. Food Policy, 26(4), 315-331. http://dx.doi.org/10.1016/S0306-9192(01)00014-8

Batterbury, S., Warren, A., Osbahr, H., Taylor, N., Skidmore, D., Seyni, S., Weigl, M., ... Chappell, A. (1999). Land-use and land degradation in SW Niger: change and continuity. SERIDA GEC Report to ESRC.

Benjaminsen, T. A., Holden, S., Lund, C., \& Sjaastad, E. (2009). Formalisation of land rights: Some empirical evidence from Mali, Niger and South Africa. Land Use Policy, 26(1), 28-35. http://dx.doi.org/10.1016/j.landusepol.2008.07.003

Boureima, A. (1994). Crise alimentaire et conquete agricole des nouvelles terres dans le Sud-Ouest du Niger. Revue de geographie alpine 2(hors serie), 171-184.

Boureima, A. (2004). Patrimoine communautaire et conflits d'usage dans deux villages du Zarmaganda au Niger. Revue de geographie alpine, 92(1), 83-96. http://dx.doi.org/10.3406/rga.2004.2281

Boutrais, J. (2007). Crises écologiques et mobilités pastorales au Sahel: les Peuls du Dallol Bosso (Niger). Secheresse, 18(1), 5-12.

Bouzou, I. M. (2000). Gestion des resources naturelles et evolution des systemes agrcoles dans la region de Maradi. Working Paper 28. 24.

Bouzou, I. M., Baechler, A., Yamba, B., \& Garba, M. (1996). La dynamique des paysages agraires dans deux terroirs villageois de Dallol Bosso: Boye-Bangou et Winde-Bago. Annales de l'universite Abdou Moumouni de Niamey, Theme agri-cultures en mutation hors serie, 57-74.

Bruce, J. W., \& Knox, A. (2009). Structures and Stratagems: Making Decentralization of Authority over Land in $\begin{array}{llll}\text { Africa } & \text { Cost-Effective. } & \text { World } & \text { Development, }\end{array}$ http://dx.doi.org/10.1016/j.worlddev.2008.08.011

Drylands_Research. (no date). Drylands Research. Retrieved September, 2012, from http://www.drylandsresearch.org.uk/

Eurostat. (2000). Manual of concepts on land cover and land use information systems. European Commission, Luxembourg.

FAO (Food and Agricultural Organisation of the Uited Nations). (2012). FAO stats. Retrieved from www.faostats.org

Geist, H., \& Lambin, E. (2001). What drives tropical deforestation?: a meta-analysis of proximate and ultimate causes of deforestation based on sub-national case study evidence. LUCC Report Series 4. Department of Geography, Louvain-la-Neuve, Belgium.

GLP. (2005). GLP Science Plan and Implementation Strategy IGBP Report No. 53/IHDP Report No. 19. IGBP Secretariat, Stockholm.

Gray, L. C. (1999). Is land being degraded? A multi-scale investigation of landscape change in southwestern $\begin{array}{llll}\text { Burkina Faso. Land Degradation \& Development, } 10(4), & 329-343 .\end{array}$ http://dx.doi.org/10.1002/(SICI)1099-145X(199907/08)10:4<329::AID-LDR361>3.0.CO;2-I

Heasley, L., \& Delehanty, J. (1996). The politics of manure: Resource tenure and the agropastoral economy in Southwestern Niger. Society \& Natural Resources, 9(1), 31-46. http://dx.doi.org/10.1080/08941929609380950

Hersperger, A. M., Gennaio, M. P., Verburg, P. H., \& Burgi, M. (2010). Linking Land Change with Driving Forces and Actors: Four Conceptual Models. Ecology and Society, 15(4).

Issa, B., \& Yamba, B. (2009). Changements climatiques er dynamique fonciere dans le systeme de cuvettes oasiennes du sud-est nigerien. Revue des sciences environnementales de l'Universite de Togo, 5, 51-62.

Issiaka, I., Yamba, B., \& Gu, Y. (2012). Land-Use and Land-Cover Change in Semi-Arid Zone: The Case of Waro-Souloulou Area in Goulbi Maradi Watershed in the Republic of Niger. Environment and Natural Resources Research, 2(1), 47-62. http://dx.doi.org/10.5539/enrr.v2n1p47 
Kanembou, L., Ambouta, J. M. K., \& Mato, M. W. (2009). Dynalique des aires pastorales dans le departement de Goure: apport de la teledetection et du SIG. Revue des sciences environnementales de l'Universite de Togo, 5, 119-143.

Lambin, E. F., \& Geist, H. J. (2006). Land-use and land-cover change. Local processes and global impacts. Springer, Berlin. http://dx.doi.org/10.1007/3-540-32202-7

Lavigne-Delville, P., Toulmin, C., Colin, J. P., \& Chaveau, J. P. (2001). Securing secondary rights to land in West Africa. Drylands Programme Issue Paper 107. IIED, London.

Leblanc, M. J., Favreau, G., Massuel, S., Tweed, S. O., Loireau, M., \& Cappelaere, B. (2008). Land clearance and hydrological change in the Sahel: SW Niger. Global and Planetary Change, 61(3-4), 135-150. http://dx.doi.org/10.1016/j.gloplacha.2007.08.011

Lund, C. (1998). Struggles for land and political power. On the politization of land tanure and disputes in Niger. Journal of legal pluralism, 40, 1-22.

Mahamane, A. (2001). Usages des terres et evolutions vegetales dans le departement du Maradi. Working Paper 27. Crewkerne, Somerset, 35.

Marichatou, H., Yamba, B., Drame, Y. A., \& Amoukou, I. (2007). Vunerabilite et innovations paysannes. Presses universitaires de Louvain, Louvain-la-Neuve, Belgique.

Mato, M. W. (2000). Les cultures de contre-saision dans le sud de la région de Zinder (Niger). Institut de Geograpgie de L'Universite de Lausanne. Lausanne. Doctoral thesis, 483.

Mato, M. W. (2004). Elevage et ressources en eau dans le Nord de la région de Zinder (Niger). Revue de geographie alpine, 92(1), 39-48. http://dx.doi.org/10.3406/rga.2004.2275

Mato, W. M. (1996). Quelques facteurs de changement des systemes agraires sahelies: le cas des milieux humides du Sud du departement de Zinder. Annales de l'universite Abdou Moumouni de Niamey, Theme agri-cultures en mutation hors serie, 233-256.

Mbow, C., Mertz, O., Diouf, A., Rasmussen, K., \& Reenberg, A. (2008). The history of environmental change and adaptation in eastern Saloum-Senegal-Driving forces and perceptions. Global and Planetary Change, 64(3-4), 210-221. http://dx.doi.org/10.1016/j.gloplacha.2008.09.008

Mohamadou, A., \& Tremolieres, M. (2007). Cross-Border Cooperation Between Niger and Nigeria. The Case of the Maradi Micro-Region. In (Eds.) Micro-Regionalism in West Africa. Nordic Africa Institute, Uppsala, Sweden.

Mortimore, M. J., \& Adams, W. M. (2001). Farmer adaptation, change and 'crisis' in the Sahel. Global Environmental Change-Human and Policy Dimensions, 11(1), 49-57. http://dx.doi.org/10.1016/S0959-3780(00)00044-3

Mortimore, M., \& Turner, B. (2005). Does the Sahelian smallholder's management of woodland, farm trees, rangeland support the hypothesis of human-induced desertification? Journal of Arid Environments, 63(3), 567-595. http://dx.doi.org/10.1016/j.jaridenv.2005.03.005

Mounkaila, F., Saidou, A., \& Sidibe, A. (1997). Perception du milieu et dynamique des pratiques de gestion a Boye Bangou et Winde Bago. Pratique de gestion de l'environnement dans les pays tropicaux, Talence, VIe Journées de Géographie Tropicale du Comité National de Géographie, Commission 'Espaces tropicaux et leur developpement'.

Mounkaila, H. (2002). De la migration circulaire à l'abandon du territoire local dans le Zarmaganda (Niger). Revue européenne des migrations internationales, 18(2), 161-187. http://dx.doi.org/10.4000/remi.1662

Mounkaila, H. (2005). Migrations de colonisation agricole et dynamique du peuplement dans les communes rurals de Say et de Tamou. In E. Reynard \& L. Dambo (Eds.), Vivre dans les milieux fragiles: Alpes et Sahel. Departement de Geographie Universite de Lausanne, Lausanne, 31, 149-164.

Nielsen, J. O., D'haen, S., \& Reenberg, A. (2012). Adaptation to climate change as a development project: A case study from Northern Burkina Faso. Climate and Development, 4(1), 16-25. http://dx.doi.org/10.1080/17565529.2012.660357

Nielsen, J. O., \& Reenberg, A. (2010). Temporality and the problem with singling out climate as a current driver of change in a small West African village. Journal of Arid Environments, 74(4), 464-474. http://dx.doi.org/10.1016/j.jaridenv.2009.09.019 
Osbahr, H., \& Allan, C. (2003). Indigenous knowledge of soil fertility management in southwest Niger. Geoderma, 111(3-4), 457-479. http://dx.doi.org/10.1016/S0016-7061(02)00277-X

Ouedraogo, I., Savadogo, P., Tigabu, M., Cole, R., Oden, P. C., \& Ouadba, J. M. (2009). Is Rural Migration a Threat to Environmental Sustainability in Southern Burkina Faso? Land Degradation \& Development, 20(2), 217-230. http://dx.doi.org/10.1002/Ldr.910

Ousseini, I., Bourema, A., \& Mato, M. W. (2005). Resaux de gestion coutumiere des ressources naturelles et enjeux de gestion territoriale etatique decentralisee: analyse a partir de quelques cas au Niger. In E. Reynard, \& L. Dambo (Eds.), Vivre dans les milieux fragiles: Alpes et Sahel. Institut de Geographie Universite de Lausanne, Lausanne, 31, 135-148.

Pare, S., Soderberg, U., Sandewall, M., \& Ouadba, J. M. (2008). Land use analysis from spatial and field data capture in southern Burkina Faso, West Africa. Agriculture Ecosystems \& Environment, 127(3-4), 277-285. http://dx.doi.org/10.1016/j.agee.2008.04.009

Rasmussen, L. V., \& Reenberg, A. (2012). Land use rationales in desert fringe agriculture. Applied Geography, 34, 595-605. http://dx.doi.org/10.1016/j.apgeog.2012.03.005

Reardon, T., Kelly, V., Crawford, E., Diagana, B., Dione, J., Savadogo, K., \& Boughton, D. (1997). Promoting sustainable intensification and productivity growth in Sahel agriculture after macroeconomic policy reform. Food Policy, 22(4), 317-327. http://dx.doi.org/10.1016/S0306-9192(97)00022-5

Reenberg, A. (2012). Insistent dryland narratives: Portraits of knowedge about human-environmental interactions in Sahelian environment policy documents. West African Journal of Applied Ecology, 20(1), 97-111.

Reenberg, A., Nielsen, T. L., \& Rasmussen, K. (1998). Field expansion and reallocation in the Sahel - land use pattern dynamics in a fluctuating biophysical and socio-economic environment. Global Environmental Change-Human and Policy Dimensions, 8(4), 309-327.

Reenberg, A., Rasmussen, L. V., \& Nielsen, J. O. (2012). Causal relations and land use transformation in the Sahel: conceptual lenses for processes, temporal totality and inertia. Geografisk Tidsskrift-Danish Journal of Geography, 112(2), 159-173. http://dx.doi.org/10.1080/00167223.2012.741888

Reij, C. P., \& Smaling, E. M. A. (2008). Analyzing successes in agriculture and land management in Sub-Saharan Africa: Is macro-level gloom obscuring positive micro-level change? Land Use Policy, 25(3), 410-420. http://dx.doi.org/10.1016/j.landusepol.2007.10.001

Rudel, T. K. (2008). Meta-analyses of case studies: A method for studying regional and global environmental change. Global Environmental Change-Human and Policy Dimensions, 18(1), 18-25. http://dx.doi.org/10.1016/j.gloenvcha.2007.06.001

Ruelland, D., Levavasseur, F., \& Tribotte, A. (2010). Patterns and dynamics of land-cover changes since the 1960s over three experimental areas in Mali. International Journal of Applied Earth Observation and Geoinformation, 12, S11-S17. http://dx.doi.org/10.1016/j.jag.2009.10.006

Saley, B. Z. (1999). Impact de la variabilite pluviometrique sur le developpement agricole en milieu sahelien. Cas des arrondissements de Kollo et Filigue au Niger. Actes du colloque SPP/E tenu à Niamey (Niger) du 10 au 11 décembre 1997 sur le thème: Méthodes pour comprendre et mesurer les pratiques agraires en milieu tropical et leurs transformations., Niamey, Institut de Geographie Universite de Lausanne, Departement de Geographie Universite Abdou Moumouni.

Saqalli, M. (2008). Populations, Farming systems and Social transitions in Sahelian Niger: An Agent-based Modeling Approach. Département des Sciences du Milieu et de l'Aménagement du Territoire. Louvain-la-Neuve, Belgium, University of Louvain-la-Neuve.

Seto, K. C., Reenberg, A., Boone, C. G., Fragkias, M., Haase, D., Langanke, T., Marcotullio, P., ... Simon, D. (2012). Urban land teleconnections and sustainability. Proceedings of the National Academy of Sciences of the United States of America, 109(20), 7687-7692. http://dx.doi.org/10.1073/pnas.1117622109

Seyni, H. (2000a). Évolution a long terme des productions agricoles, du systeme de commercialisation et des prix des produits dans la zone de Maradi. Working Paper 32, 33.

Seyni, H. (2000b). Politiques nationales et investissement dans les petites exploitations agricoles a Maradi. Working Paper 33, 39. 
Sidikou, A. H. (1977). La strategie adaptive et ses limites des Zarma du Zarmaganda (Republique du Niger) face a la secheresse actuelle (1965-1976). In J. Gallais (Eds.) Elevage et contacts entre pasteurs et agriculteurs, strategies pastorales et agricoles des saheliens durant la secheresse 1969-1974. Secrétariat d'État aux universités, Centre national de la recherche scientifique, Centre d'études de géographie tropicale, Talence. 30, 141-167.

Tappan, G. G., Sall, M., Wood, E. C., \& Cushing, M. (2004). Ecoregions and land cover trends in Senegal. Journal of Arid Environments, 59(3), 427-462. http://dx.doi.org/10.1016/j.jaridenv.2004.03.018

Thebaud, B. (1996). Gestion de l'espace et crise pastorale au Sahel, Etudes comparatives du Niger Oriental et du Yagba Burkinabé. EDHESS. Paris. PhD Geography.

Thebaud, B., \& Batterbury, S. (2001). Sahel pastoralists: opportunism, struggle, conflict and negotiation. A case study from eastern Niger. Global Environmental Change-Human and Policy Dimensions, 11(1), 69-78. http://dx.doi.org/10.1016/S0959-3780(00)00046-7

Turner, B. L., Lambin, E. F., \& Reenberg, A. (2007). The emergence of land change science for global environmental change and sustainability. Proceedings of the National Academy of Sciences of the United States of America, 104(52), 20666-20671. http://dx.doi.org/10.1073/pnas.0704119104

Turner, M. D. (1999). Merging local and regional analyses of land-use change: The case of livestock in the Sahel. Annals of the Association of American Geographers, 89(2), 191-219. http://dx.doi.org/10.1111/1467-8306.00142

van Vliet, N. , Reenberg, A., \& Rasmussen, L.V. (2013). Scientific documentation of crop land changes in the Sahel: A half empty bow of knowledge to support policy. Journal of Arid Environments, 95, 1-13. http://dx.doi.org/10.1016/j.jaridenv.2013.03.010

Wardell, D. A., Reenberg, A., \& Tettrup, C. (2003). Historical footprints in contemporary land use systems: forest cover changes in savannah woodlands in the Sudano-Sahelian zone. Global Environmental Change-Human and Policy Dimensions, 13(4), 235-254. http://dx.doi.org/10.1016/S0959-3780(03)00056-6

Wood, E. C., Tappan, G. G., \& Hadj, A. (2004). Understanding the drivers of agricultural land use change in south-central Senegal. Journal of Arid Environments, 59(3), 565-582. http://dx.doi.org/10.1016/j.jardinev.2004.03.022

Yamba, B. (1997). L'evolution de la gestion de l'environnement au Sahel: l'exemple du terroir de Sharken-Haoussa (Maradi, Niger). Pratique de gestion de l'environnement dans les pays tropicaux, Talence, VIe Journées de Géographie Tropicale du Comité National de Géographie. Commission 'Espaces tropicaux et leur developpement'.

Yamba, B. (2000). Évolution des regimes de propriete et d'utilisation des ressources naturelles dans la region de Maradi. Working Paper 29, 47.

Yamba, B. (2004). Les mutations des systèmes agraires et des modes d'usage des ressources naturelles dans la zone centrale du Niger. Revue de geographie alpine, 92(1), 97-110. http://dx.doi.org/10.3406/rga.2004.2282

Yamba, B. (2005). Stratégies de sécurisation et évolution des structures sociales de production dans les systèmes agraires du Centre-Sud du Niger. In E. Reynard \& L. Dambo (Eds.) Vivre dans les milieux fragiles: Alpes et Sahel. Departement de Geographie Universite de Lausanne, Lausanne, 31, 227-236.

Yamba, B., \& Boureima, A. (1996). Innovations paysannes et facteurs de dynamisme: le cas de deux milieux du Dallol Bosso sud (winde-Bago et Boye-Bangou). Annales de l'universite Abdou Moumouni de Niamey, Theme agri-cultures en mutation hors serie, 257-270.

Yamba, B., Bouzou, I. M., \& Boureima, A. (1997). La dynamique des systemes agraires dans le sud-ouest nigerien: le cas des cultures de contre-saison dans la region de Boboye. Pratique de gestion de l'environnement dans les pays tropicaux, Talence.

\section{Copyrights}

Copyright for this article is retained by the author(s), with first publication rights granted to the journal.

This is an open-access article distributed under the terms and conditions of the Creative Commons Attribution license (http://creativecommons.org/licenses/by/3.0/). 